\title{
PENGARUH PERSEDIAAN TERHADAP PENJUALAN PADA PT BINA TAMA INTI BUSANA (Studi Empiris pada PT Bina Tama Inti Busana tahun 2010-2015)
}

\author{
Siti Zulaekha ${ }^{1}$, Hidayat Darwis ${ }^{2}$ \\ ${ }^{1}$ STIE Muhammadiyah Jakarta, Zulaikasaputra94@gmail.com \\ ${ }_{2}^{2}$ STIE Muhammadiyah Jakarta, hidayat_mm@yahoo.co.id
}

\begin{abstract}
ABSTRAK
Pada umumnya perusahaan didalam menjalankan usahanya didalam perdagangan tentunya persediaan barang dagangan sangat bereperan dalam menunjang jalannya perdagangan. Penjualan merupakan salah satu kegiatan penting didalam perusahaan perdagangan karena dari hasil penjualan suatu perusahaan dapat dinilai baik tidaknya dalam menjalankan usahanya.Penelitian ini bertujuan untuk menganalisis pengaruh persediaan terhadap penjualan baik secara simultan maupun secara parsial pada perusahaan BTIB dibidang perdagangan tekstil di Jakarta. Jenis data yang digunakan dalam penelitian ini data sekunder. Metode analisis data yang digunakan adalah metode analisis regresi linier sederhana (R), metode koefisien determinasi $\left(\mathrm{R}^{2}\right)$, Uji asumsi klasik, uji koefisien regresi, uji hipotesis, uji statistik $\mathrm{F}$, uji statistik t. Hasil penelitian menunjukkan bahwa terdapat pengaruh secara sigifikan Persediaan (X) terhadap Penjualan (Y).
\end{abstract}

Kata Kunci : Persediaan, Penjualan

\section{ABSTRACT}

In general, companies in carrying out their business in trade, of course, inventory of merchandise is very prominent in supporting the course of trade. Sales is one of the important activities in a trading company because the results of the sale of a company can be assessed whether or not good in running its business. This research aims to analyze the effect of inventory on sales both simultaneously and partially on BTIB companies in the textile trade in Jakarta. The type of data used in this study is secondary data. The data analysis method used is a simple linear regression analysis $(R)$, the coefficient of determination $(R 2)$, the classic assumption test, the regression coefficient test, the hypothesis test, the F statistical test, the statistical test $t$. The result shows that a significant influence of Inventory $(X)$ on Sales $(Y)$.

Keywords : Inventory, Sales

\section{PENDAHULUAN}

Dalam suatu perusahaan persediaan mempunyai arti penting karena akan mempengaruhi tingkat produksi maupun penjualan. Persediaan barang dagang untuk perusahaan dagang adalah persediaan barang yang akan dijual kembali tanpa mengubah bentuk barang tersebut sedangkan persediaan barang jadi meliputi produk-produk olahan yang siap untuk dijual kepada para konsumen.

Setiap perusahaan, apakah itu perusahaan dagang ataupun manufaktur selalu mengadakan persediaan, tanpa adanya persediaan yang optimal para pengusaha akan dihadapkan pada resiko bahwa perusahaannya pada suatu waktu tidak dapat memenuhi keinginan konsumen yang memerlukan atau meminta produk yang diperdagangkan.

Hal ini mungkin terjadi, karena tidak selamanya produk-produk tersedia pada setiap saat yang berarti pula bahwa perusahaan akan kehilangan kesempatan untuk menjual produk yang dijual dan kehilangan kesempatan memperoleh keuntungan yang seharusnya didapatkan oleh perusahaan. Persediaan 


\section{JURNAL AKUNTANSI, Vol. 7, No. 2, November (2018)}

merupakan bagian utama dari modal kerja yang merupakan Aktiva penting yang pada setiap saat mengalami perubahan. Semakin tinggi tingkat perputarannya atau semakin cepat perputaranya berarti makin pendek tingkat dana dalam persediaan sehingga dibutuhkan dana yang relatif kecil. Sebaliknya semakin rendah tingkat perputaran atau semakin lambat perputaranya berarti semakin panjang terikatnya dana dalam persediaan.

Masalah yang terjadi didalam persediaan adalah kesulitan dalam menentukan besarnya jumlah persediaan yang harus disediakan dalam memenuhi jumlah permintaan, karena sering terjadinya didalam suatu perusahaan mempunyai jumlah persediaan yang terlalu sedikit dibandingkan dengan permintaan konsumen. (Basri 2010).

Pada perusahaan yang bergerak dibidang perdagangan, sangat erat kaitannya dengan ketersediaan persediaan digudang untuk menjaga operasional penjualan diperusahaan. Permasalah yang sering terjadi pada persediaan yaitu banyaknya risiko keterlambatan barang persediaan yang datang dengan barang yang akan dijual dan juga kerusakan barang dagang yang akan dijual dan juga masalah yang sering terjadi dalam persediaan tidak tepatnya jumlah persediaan barang yang ada dengan jumlah barang yang benar-benar dibutuhkan pada saat terjadi. Apabila jumlah persediaan barang yang terlalu sedikit dibandingkan dengan yang dibutuhkan akan mengakibatkan perusahaan kehilangan salah satu konsumennya karena barang yang hendak dibeli tidak tersedia dan menimbulkan kesan yang kurang baik terhadap perusahaan.

Permintaan kebutuhan jumlah persediaan barang dagang yang tidak pasti dalam tiap periodenya membuat perusahaan kesulitan dalam memperkirakan kebutuhan persediaan barang dagang untuk masa yang akan datang. Ketidaktepatan dalam menentukan waktu dan jumlah persediaan barang dagang yang akan dipesan mengakibatkan kehabisan stok dan keterlambatan dipenuhinya pesanan barang oleh supplier. Tidak hanya itu jumlah persediaan yang menumpuk atau tidak terjual akibat dari pembeliaan yang tidak efisien dan penjualan yang tidak memadai juga dapat membebani perusahaan dalam penjualan karena berpengaruh pada besarnya laba yang akan diperoleh perusahaan. Menurut Cintya Dewi Farhana dkk ( 2016) (1) ada pengaruh signifikan secara simultan dari Perputaran persediaan (X1), dan Pertumbuhan penjualan (X2) terhadap profitabilitas (Y) sebesar 70,2\%. (2) ada pengaruh yang positif dan signifikan secara parsial Perputaran persediaan (X1) terhadap profitabilitas (Y) sebesar 64,3\% dan Pertumbuhan penjualan (X2) terhadap profitabilitas (Y) sebesar $50,2 \%$ berdasarkan penelitian di PT Ambara Madya Sejati di Singaraja tahun 2012-2014.

Penjualan adalah kegiatan untuk menukarkan barang dan jasa khususnya dengan uang. Bagi setiap perusahaan, baik itu perusahaan jasa, dagang maupun perusahaan manufaktur, penjualan merupakan suatu aktivitas yang utama. Penjualan berarti menentukan perkiraan besarnya tingkat penjualan pada waktu yang akan datang. Hal ini dikarenakan dari penjualan, perusahaan memperoleh uang masuk yang akan digunakan untuk menunjang kegiatan operasi perusahaan dan kelangsungan hidup perusahaan.

Dari penjualan pula sebagian besar pendapatan perusahaan diperoleh. Penjualan merupakan pendapatan utama perusahaan karena jika aktivitas penjualan produk maupun jasa tidak dikelola dengan baik maka secara langsung dapat merugikan perusahaan. Hal ini dapat disebabkan karena sasaran penjualan yang diharapkan tidak tercapai dan pendapatan pun akan berkurang. Dengan tingkat penjualan yang tinggi, perusahaan dapat meraih keuntungan yang optimal. Dimana keuntungan dan kepuasan pelanggan merupakan ukuran penilaian dari keberhasilan suatu perusahaan dan keberlangsungan hidup perusahaan (Komaruddin 2010: 76).

Penjualan merupakan kriteria penting untuk menilai profitabilitas perusahaan dan merupakan indikator utama atas aktivitas perusahaan. Pertumbuhan penjualan adalah kenaikan jumlah penjualan dari tahun ke tahun atau dari waktu ke waktu . Pertumbuhan penjualan memiliki pengaruh yang strategis bagi perusahaan karena pertumbuhan penjualan ditandai dengan peningkatan market share yang akan 


\section{JURNAL AKUNTANSI, Vol. 7, No. 2, November (2018)}

berdampak pada peningkatan penjualan dari perusahaan sehingga akan meningkatkan profitabilitas dari perusahaan.

Menurut Eka Setifani A ( 2016) ada pengaruh signifikan secara simultan dari variabel Pertumbuhan penjualan (X1), Perputaran kas (X2), Perputaran persediaan (X3), Ukuran perusahaan (X4), dan Perputaran aktiva (X5) terhadap Return On Asset (Y). Hasil penelitian ini menunjukkan variabel perputaran persediaan dan pertumbuhan penjualan berpengaruh signifikan secara parsial terhadap Return On Asset. Dari hasil koefisien determinasi sebesar 90,45\% hal ini berarti kemampuan variabel independen mempengaruhi variabel dependen sebesar 90,45\%, sedangkan 9,55\% dipengaruhi oleh variabel lain yang tidak diteliti. Berdasarkan penelitian pada perusahaan SPBU di Tanggerang tahun 2012-2015.

Dari uraian diatas, maka penulis ingin mengadakan penelitian untuk menganalisis pengaruh persediaan terhadap penjualan baik secara simultan maupun secara parsial pada perusahaan BTIB dibidang perdagangan tekstil di Jakarta.

\section{KAJIAN PUSTAKA}

\section{Pengertian Persediaan Barang Dagang}

Persediaan merupakan bagian utama dari modal kerja, merupakan aktiva yang pada setiap saat mengalami perubahan .Persediaan adalah barang-barang yang dimiliki untuk dijual kembali atau digunakan untuk memproduksi barang-barang yang akan dijual (Zaki Baridwan, 2014:149).

Menurut (Donald E, Kieso yang diterjemakan oleh Emil Salim,SE (2011 : 402), "Persediaan (inventory) adalah pos-pos aktiva yang dimiliki oleh perusahaan untuk dijual dalam operasi bisnis normal, atau barang yang akan digunakan atau dikonsumsi dalam membuat kecermatan.investasi dalam persediaan biasanya merupakan aktiva lancar paling besar dari perusahaan dagang (ritel) dan manufaktur". Pendapat Warren (2011:440) mengatakan persediaan adalah "barang dagang yang disimpan untuk dijual dalam operasi bisnis perusahan, dan bahan yang digunakan dalam proses produksi atau disimpan untuk tujuan itu".Persediaan yang diperoleh perusahaan langsung dijual kembali tanpa mengalami proses produksi selanjutnya disebut persediaan barang dagang.

\section{Pengertian Penjualan}

Penjualan merupakan suatu transaksi yang melibatkan penjual dan pembeli pada kegiatan usaha dalam menyerahkan produk yang berupa barang ataupun jasa. Penjualan tunai adalah penjualan yang pembayarannya diterima sekaligus (langsung lunas). Sedangkan penjualan kredit adalah penjualan yang dilakukan secara non-tunai, dalam hal ini laba yang diharapkan adalah lebih besar daripada penjualan tunai, Sudaryono (2005:5). Penjualan adalah hasil yang diperoleh perusahaan dari penjualan barang yang dipasarkan pada periode tertentu baik secara tunai maupun kredit, Irwan (2011). Penjualan adalah proses dimana sang penjual memastikan, mengaktivasi dan memuaskan kebutuhan atau keinginan si pembeli agar dicapai manfaat baik bagi sang penjual maupun bagi sang pembeli yang berkelanjutan dan menguntungkan, Winardi (2009:13).

\section{Pertumbuhan Persediaan}

Pertumbuhan persediaan merupakan salah satu dari rasio aktivitas yang menentukan seberapa besar efesiensi investasi pada berbagai aktiva. Dengan kata lain menunjukkan bagaimana sumber daya telah dimanfaatkan secara optimal (Sartono,2010:118). Perusahaan yang pertumbuhan persediaan semakin tinggi berarti makin efesiensi, tetapi pertumbuhan persediaan terlalu tinggi juga tidak baik untuk itu perlu ditentukan keseimbangan ( Sartono:2010:120).

Berikut model rumus pertumbuhan persediaan yang digunakan dalam penelitian ini yaitu :

Pertumbuhan persediaan : Persediaan akhir tahun - persediaan awal tahun $\times 100$

Persediaan Awal tahun 


\section{Pertumbuhan Penjualan}

Pertumbuhan penjualan merupakan ukuran mengenai kestabilan keuangan suatu perusahaan, dengan penjualan yang relatif stabil dapat memperoleh lebih banyak pinjaman dibandingkan dengan perusahaan yang penjualannya tidak stabil. Hal ini karena investor akan lebih menyukai saham dari perusahaan yang memiliki kondisi keuangan yang baik ditandai dengan laju pertumbuhan yang tinggi, harus menyediakan modal yang cukup untuk perusahaan. Dengan mengetahui seberapa besar pertumbuhan penjualan, perusahaan dapat memprediksi seberapa besar laba yang akan didapatkan.

Untuk mengukur pertumbuhan penjualan digunakan rumus:

$$
\text { Pertumbuhan penjualan : } \frac{\mathrm{S}_{\mathrm{t}}-\mathrm{S}_{\mathrm{t}-1} \times 100 \%}{\mathrm{~S}_{\mathrm{t}-1}}
$$

Keterangan :

St $=$ Penjualan pada tahun berjalan

St $-1=$ Penjualan pada periode sebelumnya

Perusahaan yang mempunyai rasio pertumbuhan yang positif mengidentifikasikan bahwa perusahaan tersebut dapat mempertahankan posisi ekonominya dan kelangsungan hidupnya. Pertumbuhan penjualan juga menunjukkan kemampuan perusahaan dalam memasarkan barang yang diperdagangkannya.

\section{Gambar 1. Kerangka Pikir}

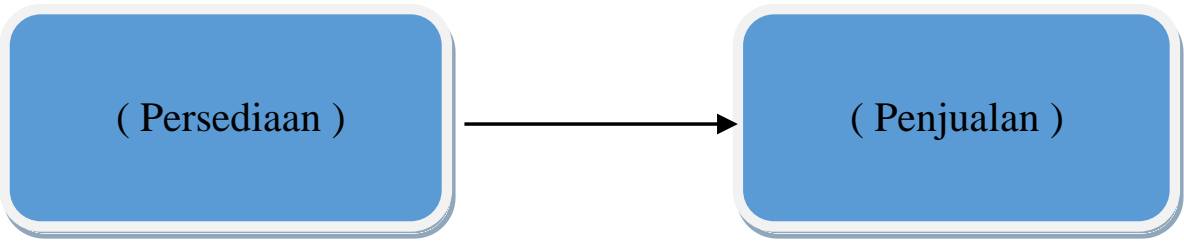

\section{Hipotesis}

Hipotesis merupakan suatu jawaban atau dugaan sementara terhadap suatu masalah yang harus diuji kebenarannya atas suatu penelitian berdasarkan data yang telah dikumpulkan. Adapun rangkaian hipotesa yang dikembangkan oleh penulis adalah :

a. $\mathrm{H}_{0}: \beta=0$, tidak terdapat pengaruh yang signifikan anatara persediaan terhadap penjualan.

b. $\quad \mathrm{H}_{\mathrm{a}}: \beta \neq 0$, terdapat pengaruh yang signifikan antara persediaan terhadap penjualan.

\section{METODE PENELITIAN}

Sampel dalam penelitian ini adalah PT BINA TAMA INTI BUSANA yang bergerak dibidang perdagangan tekstil. Data primer diperoleh langsung dari PT BINA TAMA INTI BUSANA, data yang digunakan yaitu data persediiaan bulanan dan penjualan bulanan lima tahun dan wawancara dengan karyawan di PT BINA TAMA INTI BUSANA. Penelitian ini menggunakan analisis deskriptif kuantitatif dengan metode regresi.

Metode Analisis Data

Regresi Linier Sederhana ( R ) 


\section{JURNAL AKUNTANSI, Vol. 7, No. 2, November (2018)}

Analisis Regresi merupakan suatu metode analisis yang digunakan untuk mengukur ada atau tidak adanya pengaruh variabel independen terhadap Variabel

dependen.

Adapun rumus yang digunakan yaitu :

\begin{tabular}{l}
\hline $\mathrm{Y}=\mathrm{a}+\mathrm{b}(\mathrm{X}) \quad$ dimana $:$ \\
$\mathrm{a}=$ Konstanta \\
$\mathrm{b}=$ Koefisien \\
$\mathrm{X}=$ Persediaan Barang Dagang \\
$\mathrm{Y}=$ Penjualan
\end{tabular}

Untuk mengukur dan menguji pengaruh persediaan terhadap penjualan ,maka dilakukan pengolahan data melalui persamaan regresi linier sederhana dengan menggunakan bantuan pogram SPSS.

\section{Uji Hipotesis}

Uji Signifikasi Simultan ( Uji F- test )

Menguji apakah variabel independen secara bersama-sama berepengaruh terhadap variabel dependen. Perhitungan dari ANOVA dilakukan dengan membandingkan dengan nilai kritis dari tabel distribusi F pada tingkat signifikan tertentu (Wati, 2017).

Nilai $F_{\text {hitung }}$ dapat dicari dengan rumus sebagai berikut :

$$
F_{\text {hitung }}=\frac{\mathrm{R}_{2} /(\mathrm{k}-2)}{\left(1-\mathrm{R}_{2}\right) /(\mathrm{N}-\mathrm{k})}
$$

Dimana :

$\mathrm{N}=$ Jumlah sampel

$\mathrm{K}=$ Jumlah Variabel

Pengambilan kesimpulan sebagai berikut :

a. Bila $F_{\text {hitung }}<\mathrm{F}_{\text {Tabel }}$ : maka variabel bebas secara srentak tidak berpengaruh terhadap variabel dependen.

b. Bila $\mathrm{F}_{\text {hitung }}>\mathrm{F}_{\text {Tabel }}$ : maka variabel bebas secara serentak berpengaruh terhadap variabel dependen.

\section{Uji Statistik t}

Uji statistik t dilakukan untuk mengetahui pengaruh dari masing - masing variabel independen terhadap variabel dependen ( Imam Ghozali, 2011:84).Tahap pengujian yang akan dilakukan, yaitu :

1. Hipotesis ditentukan dengan formula nol secara statistik diuji dalam bentuk:

a. Jika Ho : $\beta 1>0$, berarti ada pengaruh yang signifikan antara variabel independen terhadap variabel dependen secara parsial.

b. Jika Ho : $\beta 1=0$, berarti tidak ada pengaruh yang signifikan antara variabel independen terhadap variabel dependen secara parsial.

2. Menghitung nilai sig $\mathrm{t}$ dengan rumus :

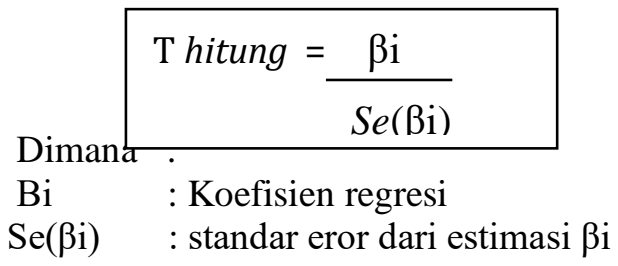


3. Derajat keyakinan (level significant $/ \alpha=5 \%$ )

a. Apabila besarnya nilai sig t lebih besar dari tingkat $\alpha$ yang digunakan, maka hipotesis yang diajukan ditolak oleh data

b. Apabila besarnya nilai sig t lebih kecil darti tingkat $\alpha$ yang digunakan, maka hipotesis yang diajukan didukung oleh data

HASIL DAN PEMBAHASAN

Pertumbuhan Persediaan

Berikut ini data pesediaan pada perusahaan BINA TAMA INTI BUSANA tahun 2010 - 2015:

Tabel 1. Data Persediaan Perusahaan PT BINA TAMA INTI BUSANA

\begin{tabular}{|l|l|}
\hline Tahun & Jumlah \\
\hline 2010 & $2,665.984 .797$ \\
\hline 2011 & $3,245.423 .030$ \\
\hline 2012 & $3,730.219 .019$ \\
\hline 2013 & $4,126.086 .534$ \\
\hline 2014 & $4,656.830 .070$ \\
\hline 2015 & $5,358.530 .533$ \\
\hline
\end{tabular}

Sumber:Data Persediaan PT BINA TAMA INTI BUSANA

Berdasarkan data diatas dapat dihitung pertumbuhan persediaan selama tahun 2010 sampai 2015 pada PT BINA TAMA INTI BUSANA.

Tabel 2. Pertumbuhan Persediaan

PT BINA TAMA INTI BUSANA

\begin{tabular}{|l|l|l|l|l|}
\hline Tahun & Persediaan & $\begin{array}{c}\text { Pertumbuhan } \\
\text { persediaan }\end{array}$ & Naik/ turun & $100 \%$ \\
\hline 2010 & 2665984797 & 23.72 & \multicolumn{1}{c|}{0} & 0 \\
\hline 2011 & 3245423030 & -69.33 & -29.228 & -29.22 \\
\hline 2012 & 3730219019 & -51.15 & 73.78 & 73.8 \\
\hline 2013 & 4126086534 & -74.86 & 1.463 & 146.3 \\
\hline 2014 & 4656830070 & 289.71 & -3.87 & -387 \\
\hline
\end{tabular}

Sumber : Data Pertumbuhan Persediaan PT BINA TAMA INTI BUSANA

Berdasarkan tabel 2. diatas dapat dijelaskan bahwa pada tahun 2010-2011 pertumbuhan persediaan mengalami penurunan sebesar $-29.22 \%$. Pada tahun 2012 - 2014 pertumbuhan persediaan mengalami pertumbuhan sebesar $73.8 \%$ dan $146.3 \%$.Kemudian pada tahun 2014 pertumbuhan persediaan mengalami penurunan kembali sebesar 3.87\%. Akan tetapi pada tahun 2015 pertumbuhan persediaan mengalami peningkatan pertumbuhan persediaan sebesar $49.6 \%$.

Dapat disimpulkan dari data diatas bahwa pertumbuhan persediaan pada PT BINA TAMA INTI BUSANA banyak mengalami peningkatan pertumbuhan persediaan pada periode - periode tahun tertentu yang membuat PT BINA TAMA INTI BUSANA mengalami peningkatan pertumbuhan persediaan.Dari pertumbuhan persediaan perusahaan PT BINA TAMA INTI BUSANA tersebut dapat disimpulkan bahwa perusahaan terus meningkatkan jumlah persediaan setiap tahunnya karena dianggap dengan kebijkan perusahaan dengan menambah persediaan untuk selanjutnya dijual di pasaran akan meningkatkan penjualan yang menghasilkan laba yang dicapai sesuai dengan keinginan perusahaan. 


\section{Pertumbuhan Penjualan}

Pertumbuhan penjualan merupakan tingkat perubahan penjualan dari tahun ke tahun yang dapat dilihat dari laporan laba rugi masing - masing perusahaan sebagai prediksi perusahaan dimasa yang akan datang sebagai dampak dari permintaan dan daya saing perusahaan. Dengan mengetahui penjualan dari tahun sebelumnya, perusahaan dapat mengoptimalkan sumber daya yang ada. Perusahaan harus menggunakan dan mengelola dengan baik sumber daya yang dimiliki untuk menghasilkan pendapatan melalui penjualan.

Dengan mengetahui seberapa besar pertumbuhan penjualan, perusahaan dapat memprediksi seberapa besar laba yang akan didapatkan. Pertumbuhan penjualan merupakan ukuran mengenai kestabilan keuangan suatu perusahaan, dengan penjualan yang relatif stabil dapat memperoleh lebih banyak pinjaman dibandingkan dengan perusahaan yang penjualannya tidak stabil. Hal ini karena investor akan lebih menyukai saham dari perusahaan yang memiliki kondisi keuangan yang baik ditandai dengan laju pertumbuhan yang tinggi, harus menyediakan modal yang cukup untuk perusahaan.

Tabel 3. Data Penjualan Perusahaan

PT BINA TAMA INTI BUSANA

\begin{tabular}{|l|l|}
\hline \multicolumn{1}{|c|}{ Tahun } & \multicolumn{1}{c|}{ Jumlah } \\
\hline 2010 & $8,493.981 .653$ \\
\hline 2011 & $9,348.965 .823$ \\
\hline 2012 & $9,896.506 .463$ \\
\hline 2013 & $9,686.454 .673$ \\
\hline 2014 & $10,663.579 .957$ \\
\hline 2015 & $55,721.453 .967$ \\
\hline
\end{tabular}

Sumber : Data Penjualan PT BINA TAMA INTI BUSANA

Tabel 4.Pertumbuhan Penjualan

PT BINA TAMA INTI BUSANA

\begin{tabular}{|l|l|l|l|l|}
\hline Tahun & Penjualan & $\begin{array}{l}\text { Pertumbuhan } \\
\text { Penjualan \% }\end{array}$ & Naik/Turun & $100 \%$ \\
\hline 2010 & 7631965398 & -58.23 & & \\
\hline 2011 & 8493981653 & $1,035.65$ & -17.78 & -1.778 \\
\hline 2012 & 9348965823 & $1,451.26$ & 0.14 & 14.0 \\
\hline 2013 & 9896506463 & 189.07 & 0.13 & 13.0 \\
\hline 2014 & 9686454673 & -72.96 & -0.38 & -38 \\
\hline 2015 & 10663579957 & -63.91 & 0.87 & 87 \\
\hline
\end{tabular}

Sumber: Data Pertumbuhan Penjualan PT BINA TAMA INTI BUSANA

Berdasarkan tabel 4 diatas dapat dijelaskan bahwa pada tahun 2010-2011 Pertumbuhan penjualan mengalami penurunan sebesar $1.778 \%$. Pada tahun 2012 pertumbuhan penjualan pada PT BINA TAMA INTI BUSANA mengalami peningkatan penjualan sebesar 14\%, kemudian pada tahun 2013 penjualan pada perusahaan kembali mengalami peningkatan penjualan sebesar 13\%. Pada tahun 2014 pertumbuhan penjualan pada perusahaan PT BINA TAMA INTI BUSANA kembali mengalami penurunan lagi sebesar $38 \%$. Setelah beberapa kali perusahaan mengalami penurunan pertumbuhan penjualan perusahaan PT BINA TAMA INTI BUSANA pada tahun 2015 mengalami peningkatan pertumbuhan penjualan sebesar $87 \%$ peningkatan yang sangat besar ini membuat perusahaan dapat mendapatkan laba yang besar dari penjualan. 


\section{JURNAL AKUNTANSI, Vol. 7, No. 2, November (2018)}

Dari hasil data pertumbuhan penjualan perusahaan PT BINA TAMA INTI BUSANA Dari hasil persentase selama enam tahun terakhir ini maka dapat disimpulkan bahwa tingkat persediaan dari tahun 2010 hingga 2015 telah terjadi peningkatan yang cukup siginfikan sehingga perusahaan pun memperoleh laba yang cukup sesuai harapan perusahaan.

\section{Pengaruh Persediaan Terhadap Penjualan pada PT BINA TAMA INTI BUSANA}

Data yang ditperoleh dari PT BINA TAMA INTI BUSANA untuk persediaan dan penjualan selama tahun 2010 - 2015 sebagai berikut:

Tabel 5. Data Persediaan Perusahaan Tahun 2010-2015

Sumber : Data Persediaan PT BINA TAMA INTI BUSANA

\begin{tabular}{|l|c|c|c|c|c|c|}
\hline \multicolumn{1}{|c|}{ BULAN } & \multicolumn{1}{|c|}{2010} & \multicolumn{1}{c}{2011} & 2012 & \multicolumn{1}{c|}{2013} & 2014 & 2015 \\
\hline Januari & $222,165,400$ & $308,566,483$ & $340,599,981$ & $389,035,714$ & $118,006,286$ & $216,269,800$ \\
\hline Februari & $274,313,429$ & $310,809,025$ & $251,218,486$ & $205,772,884$ & $179,922,050$ & $122,286,961$ \\
\hline Maret & $154,117,050$ & $273,672,666$ & $440,325,260$ & $273,672,666$ & $373,672,925$ & $113,037,999$ \\
\hline April & $185,851,912$ & $341,223,641$ & $217,514,041$ & $773,843,252$ & $433,123,640$ & $398,053,011$ \\
\hline Mei & $266,715,614$ & $173,798,179$ & $378,121,532$ & $656,647,933$ & $398,127,231$ & $663,251,765$ \\
\hline Juni & $200,603,967$ & $262,479,005$ & $406,296,808$ & $156,304,164$ & $457,682,783$ & $853,567,482$ \\
\hline Juli & $306,827,604$ & $478,154,030$ & $307,110,657$ & $380,479,100$ & $605,337,925$ & $10,161,040$ \\
\hline Agustus & $214,587,360$ & $361,199,993$ & $156,637,539$ & $290,330,821$ & $161,417,641$ & $217,514,041$ \\
\hline September & $48,081,600$ & $135,520,730$ & $203,772,884$ & $432,180,082$ & $689,035,768$ & $877,426,235$ \\
\hline Oktober & $272,508,379$ & $205,111,001$ & $372,672,666$ & $111,655,727$ & $433,918,219$ & $525,263,693$ \\
\hline November & $245,339,191$ & $300,269,000$ & $489,594,165$ & $358,382,916$ & $346,695,206$ & $834,327,052$ \\
\hline Desember & $274,873,291$ & $94,619,277$ & $166,355,000$ & $97,781,275$ & $459,890,396$ & $527,371,454$ \\
\hline TOTAL & $2,665,984,797$ & $3,245,423,030$ & $3,730,219,019$ & $4,126,086,534$ & $4,656,830,070$ & $5,358,530,533$ \\
\hline
\end{tabular}

Tabel 6. Data Penjualan Perusahaan Tahun 2010-2015

\begin{tabular}{|l|l|l|l|l|l|l|}
\hline BULAN & 2010 & 2011 & 2012 & 2013 & 2014 & 2015 \\
\hline
\end{tabular}


JURNAL AKUNTANSI, Vol. 7, No. 2, November (2018)

\begin{tabular}{|l|l|l|l|l|l|l|}
\hline Januari & $735,116,584$ & $203,298,498$ & $173,438,521$ & $762,369,423$ & $807,204,556$ & $1,636,975,561$ \\
\hline Februari & $595,091,818$ & $82,669,802$ & $918,006,286$ & $911,415,174$ & $979,250,117$ & $2,026,406,364$ \\
\hline Maret & $990,889,470$ & $429,891,496$ & $236,636,118$ & $639,468,214$ & $300,938,249$ & $1,987,032,017$ \\
\hline April & $310,768,625$ & $778,121,857$ & $845,639,041$ & $89,697,015$ & $459,593,399$ & $661,136,150$ \\
\hline Mei & $110,159,312$ & $984,561,759$ & $175,245,857$ & $310,781,818$ & $539,858,195$ & $352,025,689$ \\
\hline Juni & $99,300,056$ & $696,035,442$ & $891,136,109$ & $466,003,460$ & $393,588,381$ & $176,400,000$ \\
\hline Juli & $56,420,775$ & $139,024,738$ & $210,348,990$ & $279,391,391$ & $506,411,619$ & $328,604,478$ \\
\hline Agustus & $39,817,421$ & $89,726,686$ & $989,514,951$ & $836,272,159$ & $3,599,610,157$ & $1,494,968,441$ \\
\hline September & $1,274,313,429$ & $906,513,755$ & $1,948,950,949$ & $213,819,227$ & $99,999,890$ & $833,125,740$ \\
\hline Oktober & $2,220,870,908$ & $1,841,137,620$ & $255,762,386$ & $3,133,446,000$ & $680,903,920$ & $466,905,517$ \\
\hline November & $892,170,110$ & $34,230,000$ & $13,795,607$ & $50,000,002$ & $1,100,898,210$ & $109,372,505$ \\
\hline Desember & $307,046,890$ & $2,308,770,000$ & $2,690,491,008$ & $2,203,842,580$ & $218,197,980$ & $590,627,495$ \\
\hline Total & $7,631,965,398$ & $8,493,981,653$ & $9,348,965,823$ & $9,896,506,463$ & $9,686,454,673$ & $10,663,579,957$ \\
\hline
\end{tabular}

Sumber : Data Penjualan PT BINA TAMA INTI BUSANA

\section{Analisis Data Deskriptif Data}

Tabel 7. Hasil Deskriptif Variabel Dependen dan Variabel Independen Descriptive Statistics

\begin{tabular}{|l|c|c|c|}
\hline & Mean & Std. Deviation & N \\
\hline penjualan & 773909082.9 & 775249969.0 & 72 \\
Persediaan & 330320472.0 & 190388328.6 & 72 \\
\hline
\end{tabular}

Hasil dari uji deskriptif statistik di atas maka dapat di artikan bahwa Penjualan atau variabel dependen dengan jumlah data ( $\mathrm{N}$ ) yaitu 72 dengan rata rata 773909082,9 dan standar deviation 775249969,0. Begitu juga dengan Persediaan dimana N 72 dan rata rata 330320472,0 dengan standar deviasi 190388328,6 .

\section{Analisis Regresi Linier Sederhana (R)}

Untuk mengukur dan menguji pengaruh faktor persediaan terhadap penjualan, maka dilakukan pengolahan data melalui persamaan regresi linier sederhana dengan menggunakan bantuan pogram SPSS 20. Hasil dari pengolahan data tersebut dirangkum dalam tabel berikut ini : 


\section{JURNAL AKUNTANSI, Vol. 7, No. 2, November (2018)}

Tabel 8

Hasil Uji Koefisien Regresi

Coefficients $^{\mathrm{a}}$

\begin{tabular}{|c|c|c|c|c|c|c|}
\hline \multirow[b]{2}{*}{ Mode } & & \multicolumn{2}{|c|}{ Unstandardized Coefficients } & \multirow{2}{*}{$\begin{array}{c}\text { Standardized } \\
\text { Coefficients }\end{array}$} & \multirow[b]{2}{*}{$t$} & \multirow[b]{2}{*}{ Sig. } \\
\hline & & B & Std. Error & & & \\
\hline \multirow[t]{2}{*}{1} & (Constant) & 1425225639 & 162068295.5 & & 8.794 & .000 \\
\hline & Persediaan & -1.972 & .426 & -.484 & -4.630 & .000 \\
\hline
\end{tabular}

a . Dependent Variable : Penjualan

Sumber Output SPSS

Dari Tabel diatas, maka hasil yang diperoleh dimasukkan dalam persamaan regresi sebagai berikut :

$$
\begin{gathered}
Y=a-b X \\
Y=1425225639-1,972 X
\end{gathered}
$$

Keterangan :

$\mathrm{Y}=$ Penjualan

$\mathrm{a}=$ Konstanta

$\mathrm{b}=$ Koefisien regresi

$\mathrm{X}=$ Persediaan

Persamaan regresi sederhana dengan 1 variabel independen (bebas) yaitu penjualan, dapat dijelaskan sebagai berikut :

1. Konstanta sebesar 1425225639 : artinya jika jumlah persediaan (X) nilainya adalah 0 , maka nilai 1425225639 sebagai nilai constan untuk variabel penjualan.

2. Koefisien regresi variabel persediaan (X) sebesar -1,972 artinya setiap penambahan persediaan akan mempengaruhi penurunan ( karena ada tanda minus ) penjualan perusahaan sebesar -1,972.

Hasil dari analisis regresi diatas menunjukan bahwa persediaan memiliki hubungan negatif terhadap penjualan perusahaan yang ditunjukan dengan koefisien variabel dimana persediaan bernilai negatif.

\section{Analisis Koefisien Determinasi $\left(\mathbf{R}^{2}\right)$}

Koefisien determinasi (R2) pada intinya mengukur seberapa jauh kemampuan model dalam menerangkan variasi variabel dependennya. Nilai R2 yang mendekati satu berarti variabel - variabel independennya memberikan hampir semua informasi yang dibutuhkan untuk memprediksi variasi variabel dependen (Ghozalli, 2011). Hasil perhitungan koefisien determinasi penelitian ini dapat dilihat tabel. 


\section{JURNAL AKUNTANSI, Vol. 7, No. 2, November (2018)}

Tabel 9. Hasil Koefisien Determinasi $\left(\mathbf{R}^{2}\right)$

\begin{tabular}{|c|c|c|c|c|c|c|c|}
\hline \multirow[b]{3}{*}{ Model } & \multicolumn{7}{|c|}{ Model Summary } \\
\hline & \multirow[b]{2}{*}{$\mathrm{R}$} & \multirow[b]{2}{*}{ R Square } & \multirow[b]{2}{*}{$\begin{array}{l}\text { Adjusted R } \\
\text { Square }\end{array}$} & \multirow[b]{2}{*}{$\begin{array}{l}\text { Std. Error of } \\
\text { the Estimate }\end{array}$} & \multicolumn{3}{|c|}{ Change Statistics } \\
\hline & & & & & $\begin{array}{l}\text { R Square } \\
\text { Change }\end{array}$ & FChange & df1 \\
\hline 1 & $.484^{\mathrm{a}}$ & .234 & .224 & 683123902.8 & .234 & 21.441 & 1 \\
\hline
\end{tabular}

a. Predictors : (Constanta) Persediaan

Sumber Output SPSS

Berdasarkan output SPSS terlihat bahwa dari hasil perhitungan diperoleh nilai koefisien determinasi ( $\mathrm{R}$ square) sebesar 0,234 (nilai 0,234 adalah pengkuadratan dari koefisien korelasi atau $\mathrm{R}$ yaitu 0,484 $\mathrm{x}$ $0,484=0,234)$. Besarnya angka koefisien determinasi $\left(R^{2}\right) 0,234$ yang mengindikasikan bahwa sebesar 23,40\%. Angka tersebut mengandung arti bahwa penjualan perusahaan dipengaruhi oleh variabel persediaan sebesar $23,40 \%$. Sedangkan $(100 \%-23,40 \%=$ sisanya $76,60 \%)$ dipengaruhi oleh variabel lain diluar model regresi yang tidak diteliti. Besarnya pengaruh dari variabel lain ini disebut sebagai eror (e).Untuk menghitung nilsi eror dapat digunakan rumus $\mathrm{e}=1-\mathrm{R}^{2}$. Sebagai catatan, besarnya nilai koefisien determinasi atau $\mathrm{R}^{2}$ hanya antara $0-1$.

Sementara jika nilai $\mathrm{R}$ square minus (-), maka dapat dikatakan bahawa tidak terdapat pengaruh anatara variabel X terhadap Y. Semakin kecil nilai koefisien determinasi ( R Square), maka ini artinya pengaruh variabel bebas terhadap variabel terikat semakin lemah. Sebaliknya jika nilai $\mathrm{R}$ square semakin mendekati angka 1, maka pengaruh tersebut akan semakin kuat. Namun hasil summary pada metode determinasi $\mathrm{R}$ square hanya 0,234 itu berarti pada penelitian ini pengaruh variabel bebas terhadap variabel terikat lemah.

\section{Uji Asumsi Klasik Uji Normalitas}

Tabel 10. Hasil Uji Normalitas

One-Sample Kolmogorov-Smirnov Test

\begin{tabular}{|ll|r|}
\hline & & $\begin{array}{c}\text { Unstandardize } \\
\text { d Residual }\end{array}$ \\
\hline Normal Parameters ${ }^{\text {a,b }}$ & Mean & 72 \\
& Std. Deviation & $0 \mathrm{E}-7$ \\
Most Extreme Differences & Absolute & .133 \\
& Positive & .133 \\
& Negative & -.078 \\
Kolmogorov-Smirnov $\mathrm{Z}$ & & 1.130 \\
Asymp. Sig. (2-tailed) & & .156 \\
\hline
\end{tabular}

a. Test distribution is Normal.

b. Calculated from data. 


\section{JURNAL AKUNTANSI, Vol. 7, No. 2, November (2018)}

Hasil uji normalitas dengan menggunakan uji one - sample kolmogorov- smirnov Test diatas maka dapat dijelaskan sebagai berikut :

Apabila nilai signifikan lebih dari 0,05 maka berdistribusi secara normal dan apabila nilai signifikan kurang dari 0,05 maka tidak normal. Dapat dilihat hasil output pada uji normalitas diatas menunjukan bahwa nilai signifikan yaitu 0,158 maka hal ini dapat disimpulkan bahwa data yang kita uji berdistribusi secara normal.

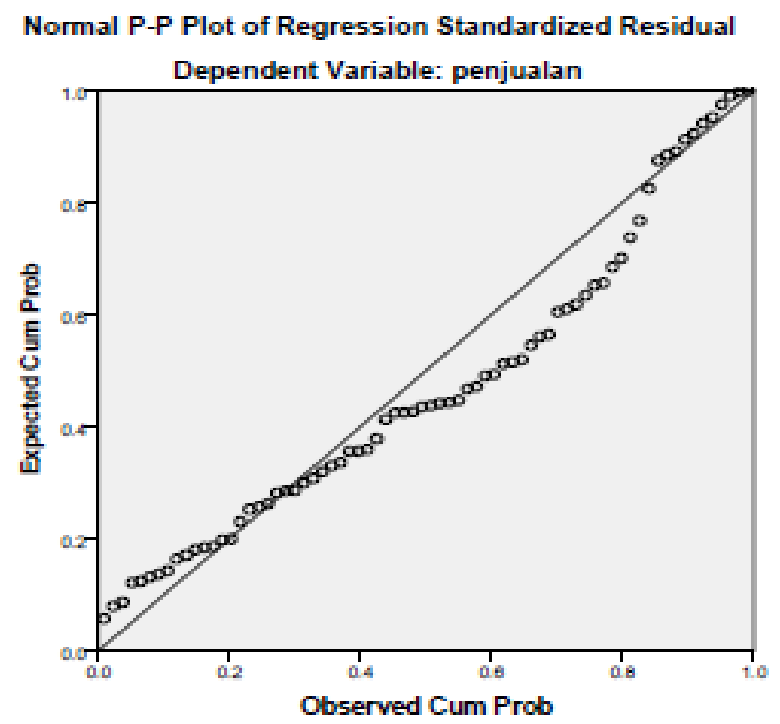

\section{Gambar 2.Hasil Uji Normalitas Berdasarkan Normal Probability P-P Plot}

Dilihat dari hasil uji normalitas probability plot, jika titik - titik disekitar garis adalah keadaan data yang diuji. Jika kebanyakan titik- titik berada sangat dekat dengan garis atau bahkan menempel pada garis, maka dapat disimpulkan bahwa data tersebut berdistribusi normal dan bila titik - titik menyebar dan menjauhi garis diagonal maka tidak berdistribusi normal.

Kesimpulan dari gambar yang dihasilkan dari uji normalitas probability plot menunjukkan bahwa data yang kita uji berdistribusi normal.

\section{Uji Autokorelasi}

\section{Tabel 11. Hasil Uji Autokorelasi}
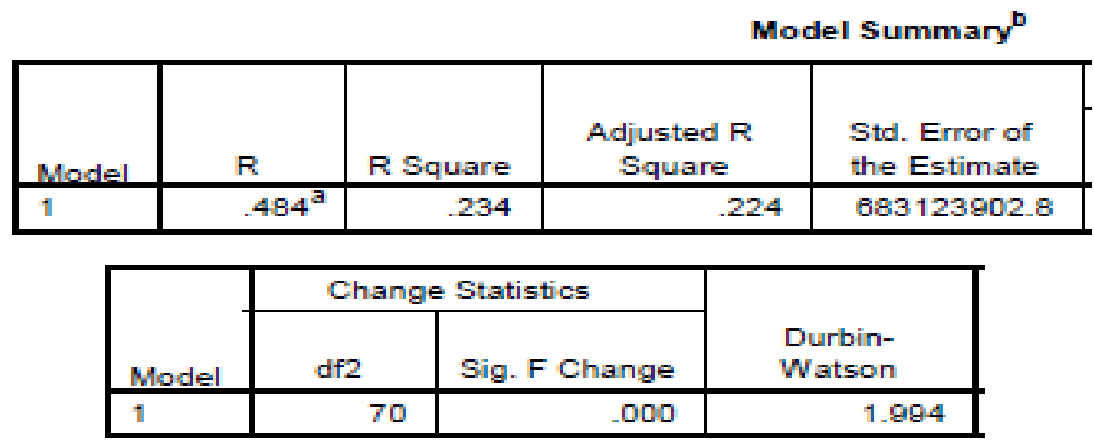
Hasil uji autokorelasi diatas, terlihat bahwa angka Durbin - Watson sebesar 1,994 > lebih 0,05. Hal ini berarti pada model tidak terjadi autokorelasi. Dengan demikian korelasi antara variabel dalam suatu model tidak dipengaruhi oleh data periode sebelumnya. Hal ini menunjukkan model penelitian tersebut tidak terjadi autokorelasi.

\section{Uji Multikorelasi}

Tabel 12. Hasil Uji Multikorelasi

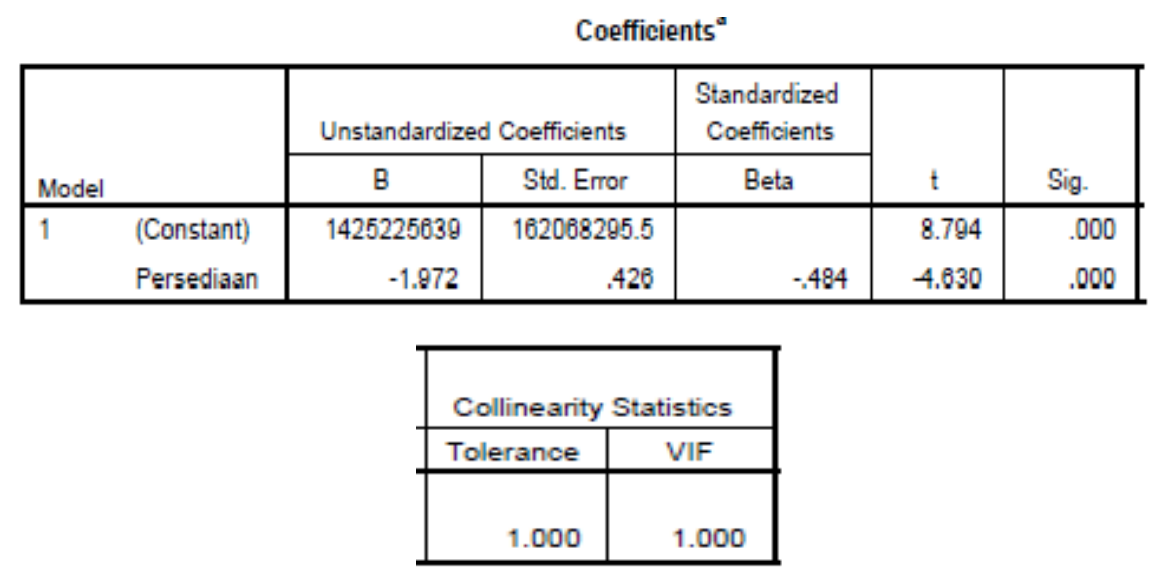

Hasil dari output data di atas dapat di lihat dari tolerance dan VIF. Apabila nilai tolerance kurang < 0.1 maka tidak terjadi multikorelasi namun apabila nilai tolerance lebih $>0.1$ maka terjadi multikorelasi. Apabila nilai VIF < 10 maka tidak terjadi multikorelasi namun apabila VIF > 10 maka terjadi multikorelasi. Di lihat dari hasil pengolahan data menunjukan bahwa nilai tolerance pada persediaan yaitu 1,000 hal ini menunjukkan berarti terjadi multikorelasi.

Sedangkan pada nilai VIF untuk persediaan yaitu 1,000 hal ini menunjukkan bahwa terjadi multikorelasi. Maka dapat disimpulkan bahwa model regresi terjadi multikorelasi.

\section{Uji Heteroskedastisitas}




\section{JURNAL AKUNTANSI, Vol. 7, No. 2, November (2018)}

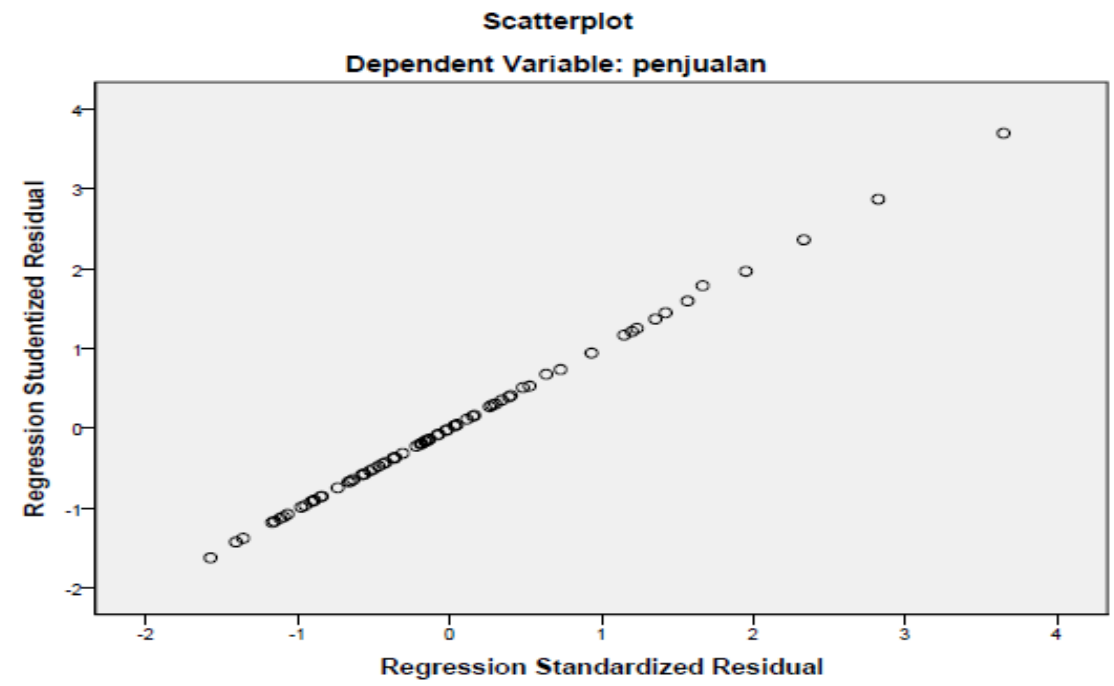

\section{Gambar 3 . Hasil Uji Heteroskedastisitas}

Metode pengambilan keputusan pada uji Heteroskedastisitas dengan melihat scatterplot yaitu jika titik-titik menyebar acak maka tidak terjadi heteroskedastisitas. Apabila titik-titik dan pola berkelompok atau garis maka terjadi heteroskedastisitas. Dapat dilihat dari hasil output diatas menunjukkan bahwa scatterplot berpola garis itu artinya bahwa uji ini terjadi heteroskedastisitas.

\section{Analisis Uji Signifikasi Simultan ( Uji F - test )}

Uji F merupakan uji variabel bebasnya terhadap variabel terikatnya. Pada bagian ini ditampilkan tabel analisis varians ANOVA.

Tabel 13. Uji F- test

ANOVA $^{\mathrm{a}}$

\begin{tabular}{|c|c|c|c|c|c|c|}
\hline Model & & $\begin{array}{l}\text { Sum of } \\
\text { Squares }\end{array}$ & df & Mean Square & $\mathrm{F}$ & Sig. \\
\hline \multirow[t]{3}{*}{1} & Regression & $1.001 \mathrm{E}+19$ & 1 & $1.001 \mathrm{E}+19$ & 21.441 & $.000^{\circ}$ \\
\hline & Residual & $3.267 \mathrm{E}+19$ & 70 & $4.667 \mathrm{E}+17$ & & \\
\hline & Total & $4.267 \mathrm{E}+19$ & 71 & & & \\
\hline
\end{tabular}

a. Dependent Variable: penjualan

b. Predictors: (Constant), Persediaan

Sumber Output SPSS

Dari hasil uji Anova atau F menunjukkan bahwa F hitung adalah $21.441>\mathrm{F}$ tabel 3,98 dan nilai dari sig 0,000 maka lebih kecil dari 0,05. Hal ini menunjukkan bahwa hasil dari uji $\mathrm{F}$ ini menunjukkan bahwa terdapat pengaruh antara variabel independen terhadap variabel dependen secara signifikan. Sehingga dapat disimpulkan bahwa persediaan berpengaruh signifikan terhadap penjualan. 


\section{JURNAL AKUNTANSI, Vol. 7, No. 2, November (2018)}

\section{Analisis Uji Statistik t}

Uji t ini digunakan untuk melihat sejauh mana pengaruh secara parsial variabel bebas yaiutu variabel persediaan. Dengan uji t dapat diperoleh informasi menegenai variabel mana yang memiliki pengaruh paling dominan. Secara parsial pengaruh dari persediaan terhadap penjualan ditunjukan pada tabel berikut :

Tabel 14. Hasil Uji Statistik t

\begin{tabular}{|c|c|c|c|c|c|c|}
\hline \multicolumn{7}{|c|}{ Coefficients ${ }^{a}$} \\
\hline \multirow[b]{2}{*}{ Model } & & \multicolumn{2}{|c|}{ Unstandardized Coefficients } & $\begin{array}{l}\text { Standardized } \\
\text { Coefficients }\end{array}$ & \multirow[b]{2}{*}{$t$} & \multirow[b]{2}{*}{ Sig. } \\
\hline & & $B$ & Std. Error & Beta & & \\
\hline 1 & (Constant) & 1425225639 & 162068295.5 & & 8.794 & .000 \\
\hline & Persediaan & -1.972 & .426 & -.484 & -4.630 & .000 \\
\hline
\end{tabular}

a. Dependent variable : Crt

Sumber Output SPSS

Uji statistik t menunjukkan seberapa jauh pengaruh variabel penjelas/ independen secara individual dalam menerangkan variasi variabel dependen. Apakah variabel independen berpengaruh secara nyata atau tidak. $\mathrm{H}_{0}$ diterima dan $\mathrm{H}_{1}$ di tolak jika nilai $\mathrm{t}$ hitung < $\mathrm{t}$ tabel atau jika nilai sig $>0.05$. $\mathrm{H}_{0}$ ditolak dan $\mathrm{H}_{1}$ diterima jika nilai $\mathrm{t}$ hitung $>\mathrm{t}$ tabel atau jika nilai sig $<0.05$. Berdasarkan persediaan $(\mathrm{X}) \mathrm{t}$ hitung 4,630 > t tabel sebesar 1.99444 dan nilai sig $0.000<0.05$. Maka dapat disimpulkan bahwa $\mathrm{H}_{0}$ ditolak dan $\mathrm{H}_{1}$ diterima yang artinya bahwa terdapat pengaruh secara sigifikan Persediaan (X) terhadap Penjualan (Y).

\section{PENUTUP}

Pertumbuhan persediaan pada PT Bina Tama Inti Busana periode tahun 2010 - 2015 mengalami pengaruh positif yang signifikan. Dapat disimpulkan persentase pertumbuhan penjualan perusahaan PT Bina Tama Inti Busana selama enam tahun terakhir ini telah terjadi peningkatan yang cukup siginfikan sehingga perusahaan memperoleh laba yang cukup sesuai harapan perusahaan.

Secara parsial terdapat pengaruh positif dan signifikan antara persediaan terhadap penjualan di perusahaan PT Bina Tama Inti Busana. Hal ini ditunjukkan dari persediaan (X) F hitung adalah $21.441>$ F tabel 3,98 dan nilai dari sig 0,000 maka lebih kecil dari 0,05. Hal ini menunjukkan bahwa hasil dari uji F memliki pengaruh positif secara signifikan antara variabel independen terhadap variabel dependen. Sehingga dapat disimpulkan bahwa persediaan berpengaruh positif dan signifikan terhadap penjualan.

Secara parsial terdapat pengaruh positif dan signifikan antara persediaan terhadap penjualan di perusahaan PT Bina Tama Inti Busana. Hal ini ditunjukkan dari variable persediaan (X) t hitung -4,630 $>$ t tabel sebesar 1.99444 dan nilai sig $0.000<0.05$. Maka dapat disimpulkan bahwa $\mathrm{H}_{0}$ ditolak dan $\mathrm{H}_{1}$ diterima yang artinya bahwa terdapat pengaruh positif secara sigifikan Persediaan (X) terhadap Penjualan (Y).

Oleh karena itu PT Bina Tama Inti Busana harus biasa mempertahankan atau lebih baik lagi dalam mengatur persediaan yang tepat dan bisa memprediksi barang yang banyak diminati oleh pelanggan dengan barang yang dijualkan untuk meningkatkan penjualan yang sudah dilaksanakan dengan baik untuk meningkatkan pendapatan didalam perusahaan. 


\section{REFERENSI}

Afrianah, E. S. (2016). Analisis Pengaruh Pertumbuhan Penjualan, Perputaran Kas, Perputaran Persediaan, Ukuran Perusahaan dan Perputaran Aktiva Terhadap Profitabilitas (Bachelor's thesis, Jakarta: Fakultas Ekonomi dan Bisnis UIN Syarif Hidayatullah Jakarta).

Agus Sartono.(2010).Manajemen Keuangan Teori dan Aplikasi.Yogyakarta:BPFE.

Cintya Dewi Farhana.2016. "Pengaruh Perputaran Persediaan Dan Pertumbuhan Penjualan Terhadap Profitabilitas PT Ambara Madya Sejati Di Singaraja Tahun 2014 - 2016 “. Skripsi. Universitas Pendidikan Ganesha Singaraja Indonesia.

Ghozali, Imam. 2011. Aplikasi Analisis Multivariate dengan SPSS. Semarang:Badan Penerbit UNDIP. Indriyo Gitosudarmo dan Basri. 2010. Manajemen Keuangan. BPFE: Yogyakarta

Irwan, (2011). Pengaruh Modal Kerja Terhadap Penjualan Pada PT. Mabar Feed Indonesia. Skripsi Fakultas Ekonomi UMSU, Medan

Kieso, Donald E. dan Jerry J. Weygandt dan Terry D. Warfield (alih bahasa Emil Salim,S.E. 2011). Akuntansi Intermediate. Jakarta: Erlangga.

Komaruddin, 2010, Ensiklopedia Manajemen, Jakarta : Bmi Aksara.

Sudaryono,(2008). Manajemen Pemasaran. Jakarta: Salemba Empat

Warren, Carl S., Reeve, James M. dan Duchac, Jonathan, 2011. Accountin Cengage Learning. Singapore Winardi,(2009). Ilmu dan Seni Menjual. Bandung: Salemba Empat

Wati, L.N. 2017. Metodologi Penelitian Terapan Bisnis: Aplikasi SPSS, EVIEWS, SmartPLS, dan AMOS. Bandung: Mujahid Press.

Zaki Baridwan, 2014. Intermediate Accounting. BPFE Fakultas Ekonomi UGM: Yogyakarta 